\title{
Bright future
}

\section{Chile excels at stargazing, but it must boost its expertise to find its place in a globalized world and develop a twenty-first-century economy.}

\section{BY ALESZU BAJAK}

arly this year, in the middle of the Atacama Desert, Chile started building what will be one of the world's biggest telescopes. The European Extremely Large Telescope (E-ELT), slated to cost more than US $\$ 1$ billion and debut in 2024, will no doubt boost the country's already massive output of astronomy and astrophysics research. In 2016, Chile published around 1,300 studies in those fields.

But it is no oversight that the telescope has been named after a continent 10,000 kilometres away. The crystal-clear skies of the Atacama will have made the region a hub for $70 \%$ of the world's astronomical observation by 2020 , and a shining star of international space research, but Chile itself has had only a partial part to play. Investment in astronomy from universities and research institutes based overseas has been the main driver; the E-ELT, for example, was funded by member states of the European Southern Observatory, such as Germany, France and the United Kingdom.

This reliance on foreign money and influence is reflective of a larger phenomenon. Chile has struggled to excel in other scientific fields, and it invests very little - less than $0.5 \%$ of its gross domestic product (GDP) - in science and technology.

That's made Chilean scientists angry. The past few years have been marked by a vociferous debate over who should fund science, with incensed researchers taking to the streets to protest over scarcity of resources. They're eager to point out that Brazil dedicates close to $1 \%$ of its GDP to research and development; in the United States, the figure is $2.8 \%$. Government shortsightedness, scientists say, has repercussions beyond hampering research output and exacerbating brain drain - it could hold back Chile's economic development. The state, for its part, favours fiscal conservatism, a strategy that has buoyed the country through many crises and long set it apart from economically unstable neighbours such as Brazil and Argentina.

\section{SELLING ROCK}

In many ways, Chile's extractive economy hasn't changed in a century. Copper mining alone accounts for almost $50 \%$ of Chilean exports: it generated more than $\$ 24$ billion 
for the country in 2016. Exploiting its mineral wealth has made Chile one of Latin America's richest countries in terms of GDP per capita, trailing behind only Uruguay.

But, like the country's clear skies, this underground bounty might not benefit Chile alone.

The country once protected its coppermining rights, but in recent decades it has sold them to foreign companies. The same companies are eyeing other mineral wealth, such as Chile's vast reserves of gold and lithium in the Andes mountains. Multinational mining companies such as BHP Billiton of Melbourne, Australia, and Barrick Gold of Toronto, Canada, have established a strong presence in the country to exploit those seams, importing technology and expertise to maximize business opportunities.

Critics say that, similar to so many developing countries, Chile is busy selling off its natural resources when it should be investing in a secondary sector that adds value to raw production. And, in an era of globalization and the shifting economic fortunes that come with it, that might mean turning to something that the country has historically snubbed: science.

"Mining is the sector that generates the most money here in Chile and it invests very little in developing technology. This is extremely painful," says José Manuel Pérez, director of the Bionanotechnology and Microbiology Lab at Andrés Bello University in Santiago. Two years ago, Pérez says, he changed research tracks from studying bacteria to looking at nanotechnological applications for copper and lithium, specifically their antimicrobial and energystorage properties.

Mining companies' reluctance to invest in research and development is unfortunate, Pérez says, because Chile could be a powerhouse for producing smartphone parts, next-generation batteries or any number of products that add value to the metals it extracts. Instead, he says, companies "just sell rock".

Now, as Chile begins to scratch the surface of its lithium reserves - the world's largest Pérez fears that history will repeat itself with another missed opportunity. "We're making the same mistakes now with lithium that we made 50 years ago with copper," he says. "We should be a world power in copper and lithium technologies. We are very far from that."

\section{FAIR COLLABORATIONS}

Eduardo Bitran agrees that Chile needs a more proactive approach to taking advantage of its natural resources. For decades, Bitran, who is executive vice-president of Chilean economic-development agency Corfo, has been pushing his government colleagues to develop educational and technological infrastructure that can mature the country's economy - from one that digs, grows and sows to a knowledge hub for eco-friendly mining, genetic engineering and food security. It's a monumental task and, because the private sector isn't providing the money, Bitran sees government institutions such as Corfo as playing a key part. "Chile's private sector in general invests little in research and development," he says. "Therefore, a catalytic role is required from the state."

Bitran's strategy is simple. He advocates establishing large consortia - including stakeholders such as Chilean companies, venture capitalists and foreign companies - to bring applied research, new technologies and local talent to bear on the challenges facing specific sectors, such as hydrogen-diesel combustion for mining or genetic-improvement technology for fruit and vegetable production.

So far, Bitran has been successful in bring-

IF YOU SOLVE ONE
CHALLENG IN
CHILE,
YOU'RE PILOTING
SOLUTIONS FOR
THE GLOBE.

ing various partners to the same table. In late 2015, for instance, a group he convened for Chile's burgeoning solar-energy industry was able to tackle a problem with solar panels in the Atacama. The same desert that is prized by astronomers for its clear night skies bakes during the day under sunlight intense enough to damage conventional solar panels. Much to the consternation of renewable-energy enthusiasts, who hope that Chile could become a beacon of solar-power technology, the early solar panels installed in the Atacama were fizzling out after a year: the desert was too sunny for solar. Corfo stepped in to help find a solution.

"We had to create a consortium of Chilean research institutions and Chilean companies but also get scientific help from the Germans and the French," says Bitran. "We provided US $\$ 15$ million to develop new technologies like coatings to confront the radiation problem." Now, with more than 1,700 megawatts of installed photovoltaics, Chile generates more solar power than any other country on the continent. And in August last year, a Chilean utility company auctioned the rights to sell solar power for a mere $\$ 29.10$ per megawatt hour - half the price of coal and, at the time, the cheapest solar in the world.

Bitran's long-term dream is to develop a constellation of technical institutes up and down the country to cultivate innovators who are equipped to transform Chile's economy. He also wants the entire mining sector to run on solar energy - something he calls "green mining" because both the inexhaustible solar resources and the mining seams are in the country's arid north.

But Bitran is not optimistic about the political mountain-moving required to realize these dreams. "I've been pushing for this vision of development since the 1990s and I don't think I've been successful," he says.

With or without his technical institutes, Bitran hopes the next challenge to innovation can be solved with Chilean ingenuity. The country, he says, needs to become less dependent on technology transfer and experts from abroad - so it must invest in education. "In the end, a country needs to have a local base of knowledge."

\section{THINKING LIKE AN ENTREPRENEUR}

Others worry that a revamped education system will not drive innovation by itself. University enrolment in Chile has already roughly doubled since 2005. What is lacking is entrepreneurial spirit, says Yuly Fuentes-Medel, executive director of ChileMass, an initiative between Chile and the US state of Massachusetts set up in 2011 to promote collaboration around education, energy and biotechnology. Chilean scientists, she says, aren't accustomed to thinking about how their research translates to business.

"It's not instinctive in Chilean culture to create a company out of a lab. There's no knowledge about commercializing science," says Fuentes-Medel, who, after receiving a $\mathrm{PhD}$ in biomedical sciences, began exploring the intersection of science and industry as a postdoctoral associate at the Massachusetts Institute of Technology's Sloan School of Management in Cambridge. After some time working in Kendall Square, a hotbed of biotechnology companies and tech start-ups in Cambridge, she began to appreciate the region's entrepreneurial spirit. She says she did not see the same attitude in Chile.

"If I hit on something in a lab here in Boston, I walk down to the patent office and see if my technology is patentable. In Chile that doesn't exist. There are very few people in Chile that know how to patent an idea," says FuentesMedel.

That's why, with ChileMass, she's spreading the gospel of Chile's significant resources, which could help with developing technologies for renewable energy, mining, agriculture and medicine. The country's unusual length - taking up much of the west coast of South America - provides a host of locations and environments, from temperate forest to desert, and high summits to Patagonian fjords. Fuentes-Medel's pitch to Massachusetts-based companies, start-ups and researchers? Come and prototype your technology in the largest natural laboratory in the world. "If you solve one challenge in Chile, you're piloting solutions for the globe," she says.

Developing an entrepreneurial mindset and 


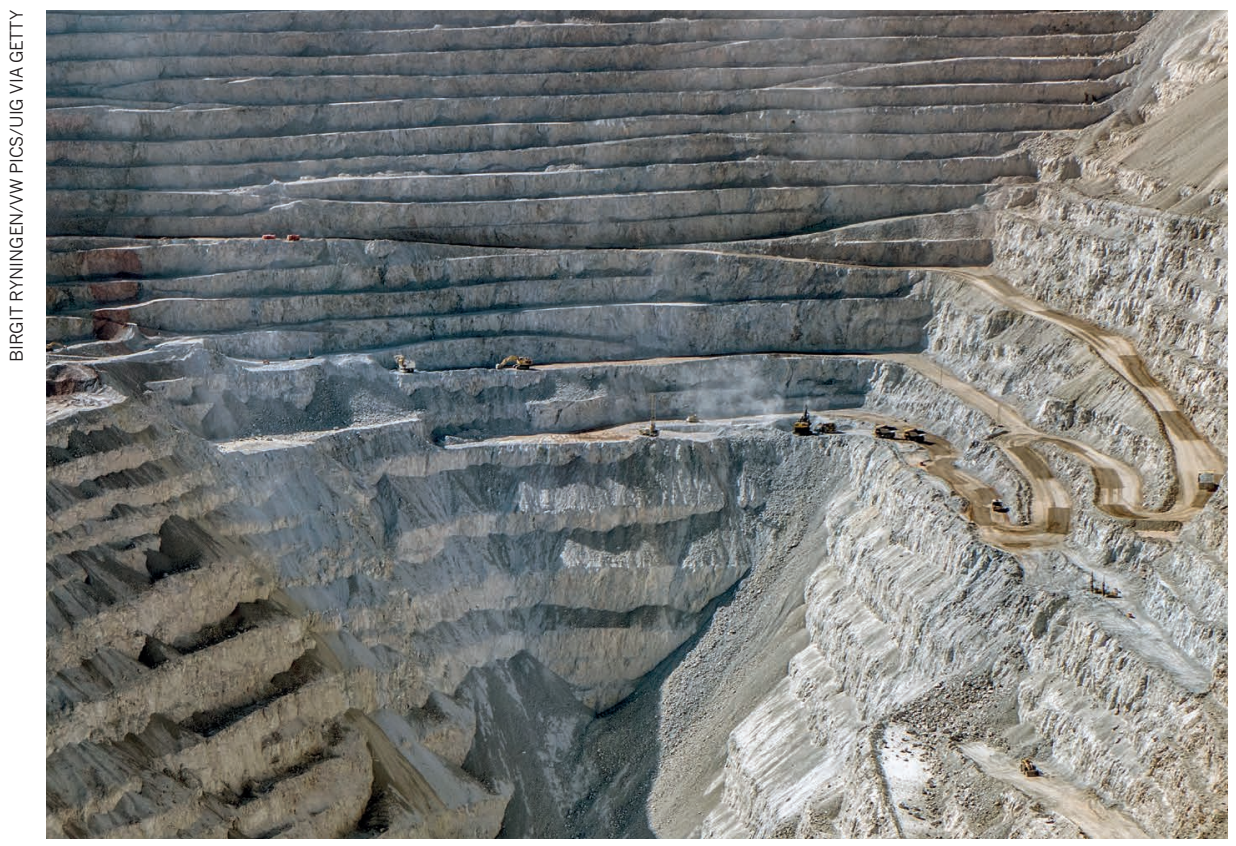

Chile's copper mines are crucial to an economy that relies on resource extraction.

adopting world-class technical skills doesn't happen overnight, says Marcos Kuperman, chief executive of Fundación Chile in Santiago, a non-profit organization that partners with the government and Chilean corporations to stimulate innovation. "Countries work on very long cycles," he says.

Like Bitran, Kuperman is a firm believer in bringing multiple people together to solve a single issue. "Solutions come from diverse groups building a common vision," he says.

\section{SALMON SUCCESS}

Kuperman points to his country's booming fish-farming sector as a case study in this collective strategy. Today, Chile is one of the world's leading salmon farmers - along with Scotland, Norway and Canada - exporting more than $\$ 4$-billion worth of the fish in 2016. That wasn't always the case. Salmon were introduced to the country by the government in 1921, but it wasn't until the 1970s and 1980s that Chile realized that the fjords of its southern coast had the potential to host floating pens to raise the fish. Fundación Chile brought together private and public financing, local knowledge and foreign technology to plan out a long-term road map for the emergence of an aquaculture industry built from scratch, and its efforts have yielded decades of dividends.

The foundation's foresight also ensured that Chilean science retained a seat at the table. The country's ecological conditions demanded local solutions to problems - with endemic fish diseases, for instance - which forced the incorporation and, in the process, the strengthening of local scientific knowledge. "Fundación Chile created not only the first salmon producer, but also the first companies that made antibiotics, water-recirculation technology and testing laboratories for aquaculture," says Kuperman. "This was a project that turned into a textbook industry."

Making sure that Chileans had a central role in the nascent industry was always a priority, says Kuperman. That will continue to be a struggle as the country moves into a more advanced economy, and as more foreign countries come hunting for rock to mine. To stay relevant and competitive, Chile must continue to develop its human capital. That, Kuperman says, might be the toughest challenge of all - it means modernizing curricula and investing in education outside the conventional classroom. "The recipes of the past in terms of education won't work to address the long list of challenges we'll have for developing twenty-first-century skills," he says.

To that end, Kuperman is investing in boot camps that expand attendees' software skills but also incentivize them to acquire social skills that spur collaboration. "It's not just about software but how one interacts with others," he says.

He's optimistic about closing the skills gap in Chile. Much of the other groundwork has been laid. "We now have incubators, research centres, venture-capital companies. We're starting to build that," he says. Despite their funding challenges, Chile's scientists are rising up to meet the country's unique problems. From its uninhabitable deserts to its powerful earthquakes, Chile has supported world-class astronomy and developed some of the best anti-seismic technology in the world, Kuperman points out.

"In Chile, we've twisted destiny's arm and are generating more unique knowledge in the country," he says. "We've turned weaknesses into strengths." -

Aleszu Bajak is a freelance science journalist who teaches at Northeastern University in Boston, Massachusetts. 


\section{OPEN YOUR MIND. \\ VENTURE INTO THE UNKNOWN. EXPAND YOUR HORIZONS.}

CONGRESO

FUTURO

ESO FUTURO A SCIENTIFIC VOYAGE DISCOVERY WHERE THE FUTURE IS OURS FOR THE MAKING
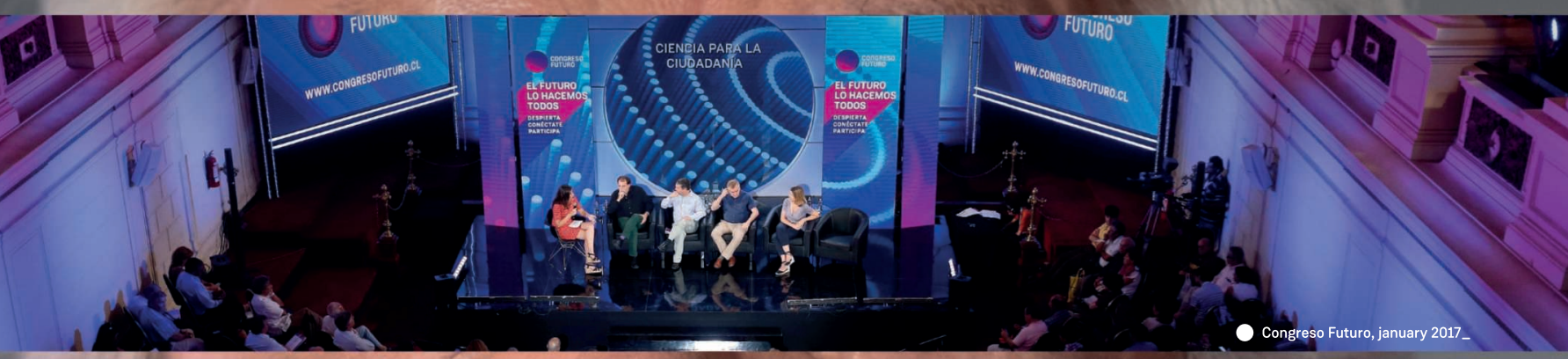

07 - Days

130 - Speakers

02 - Exclusive channels
12 - Cities

03 - Nobel Prize Winners

70 - Hours of streaming ${ }^{\text {HD }}$ 


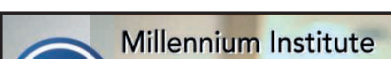

(7)imunoiogra W/W/imili.,Gl

- 0 GS: Immunology societies :

CENTERS of EXCELLENCE

MIII comprises more than 150 scientists working on pathogens, cancer, inflammation and autoimmunity to develop vaccines, novel diagnostics and innovative treatments to improve human health.

\section{Our Drive:}

-Mission-oriented basic biomedical research.

-To develop new and better strategies to prevent, detect \& treat immunology-related diseases.

-To train young immunologists in Chile on translational research.

-To transfer science and technology from the university to the society.

-To disseminate immunology to the general public.

Our Recent Achievements:

-RSV vaccine undergoing clinical evaluation.

-Cell-based cancer immunotherapy trials.

-Strategic partnerships with biotech companies.

-WIPO Gold medal award.

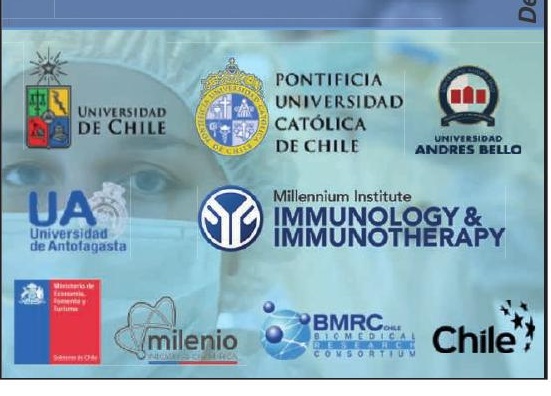




\section{BIOMEDICAL INNOVATION COMESFULL CIRCLE}

By integrating scientific discovery, entrepreneurship and public outreach, a non-profit foundation aims to put Chile on the biotechnology map.

Pablo Valenzuela had already created one of the world's largest biotechnology firms in the United States when, in 1996, he turned to his native Chile, where - together with Bernardita Méndez and Mario Rosemblatt - he created the Fundación Ciencia \& Vida (Science \& Life Foundation), a Santiago-based nonprofit institute dedicated to improving the social and economic development of Chile through biomedical research, entrepreneurship and education.

"We wanted to help the country do something important and different," says Valenzuela, now scientific director of Ciencia \& Vida.

The idea from the outset was to create a bridge institution. They started by building up the institute's research capacity and creating a technology transfer office. A PhD program in biotechnology in alliance with Universidad Andrés Bello soon followed, as did the consolidation of a science and business park, an educational program and a scientific exchange with the University of California San Francisco.

Before long, they realized, Ciencia \& Vida had become an integrated platform for research discovery, advanced training, global science, entrepreneurship and outreach. "What we were doing was leveraging science in every one of its aspects," says Méndez, president of the institute. They took their lead

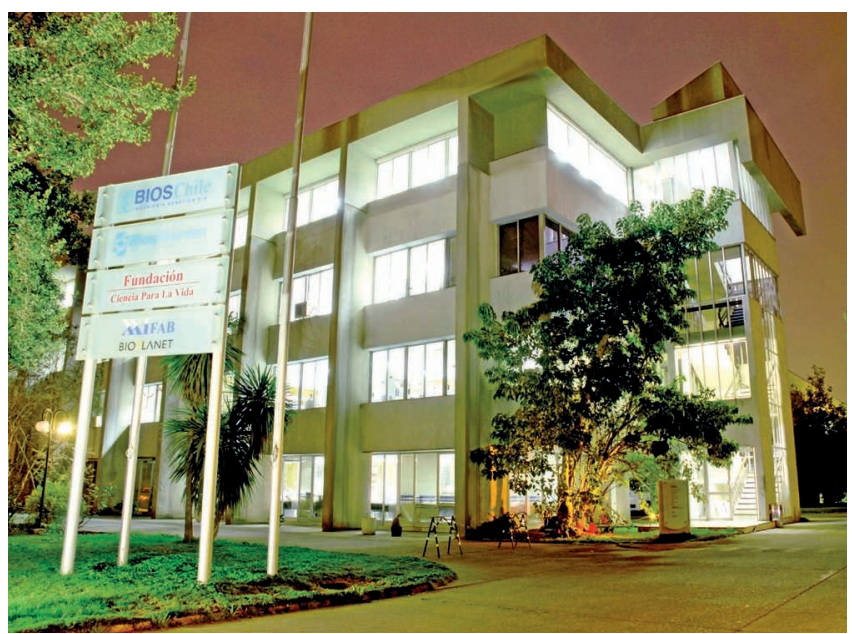

from the approach in naming it Science $360^{\circ}$.

Today, Ciencia \& Vida includes around 130 scientists working in 12 research labs in biomedicine, bio-resources and computational biology. This forms the backbone of the Science $360^{\circ}$ model, says Mario Rosemblatt, executive director. "We can only do everything else because we have good science." Today the institute is a national scientific centre of excellence and receives public funding from national agencies such as CONICYT and Corfo.

"We are strongly committed to building a scientific culture in Chile," says Carolina Torrealba, director of special projects. The institute's science

\section{BY THE NUMBERS}

FUNDACIÓN CIENCIA \& VIDA knows how to translate budget into impact.

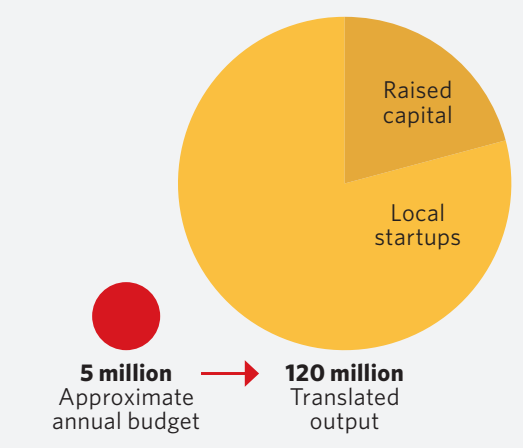

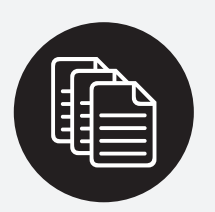

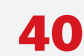

Published papers per year

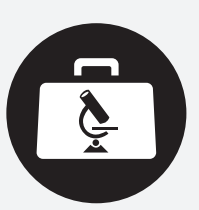

$200+$

Jobs created in high-tech companies

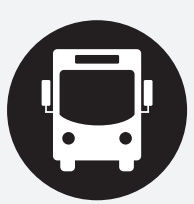

$15,000+$ Students trained in bus-mounted-lab science workshops dissemination materials range from $T V$ documentaries and animated $\mathrm{TV}$ series to video games and books. The institute also runs science workshops for key opinion leaders and is home to a bus-mounted educational lab in collaboration with Fundación Ecoscience.

\section{WE WANTED TOHELP THE COUNTRY DO SOMETHING IMPORTANT AND DIFFERENT}

Fifteen companies have set up shop on Ciencia \& Vida's science and business campus, including three international firms and 10 homegrown biotech startups, some of which were founded by graduates of the PhD program. According to Cristián Hernández, director of entrepreneurship and business development at Ciencia \& Vida, all this has been achieved with an annual budget of less than US\$5 million. "We have been able to accomplish a lot with very little," he remarks.

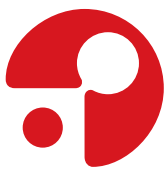

Fundación Ciencia \& Vida 


\section{UNIVERSIDAD DE CHILE: SCIENCE OF THE SOUTH}

\section{A conversation with ENNIO VIVALDI, rector of Universidad de Chile}

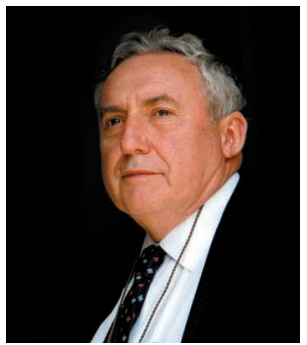

Universidad de Chile, one of the oldest and highest ranked in Latin America, was at the core of the creation of Chile's Republic nearly two centuries ago. Rector Ennio Vivaldi discusses how Universidad de Chile is fostering collaboration with South American universities to showcase the knowledge generated there.

\section{How is Universidad de Chile different?}

The role that the university has played in Chilean history is key, providing an intellectual network as well as contributing greatly to the development of critical thinking. Two Nobel Prize winners and 20 presidents have come out of our classrooms. Founded 175 years ago, in the new Republic of Chile, the institution of higher education was responsible for helping to form the identity of the nation. Subsequently, Universidad de Chile organised the national education system and in 1952 was a major contributor to the public healthcare system. In 1972 the university led huge efforts to help eradicate child malnutrition, as it was considered that Chile could not become a developed country if its citizens did not have adequate nutrition to develop cognitively. This was Chile's first truly multidisciplinary project and a pioneering one at that time. Our scientific milestones range from amazing astronomical data gathering and astronomy observatories centres to world-class breakthroughs in membrane biophysics and Humberto Maturana's autopoiesis theory. More recently, we have promoted the construction of a productive infrastructure and helped develop earthquake-resistant engineering. The university has a different function than it would in other countries, as evidenced by its ownership of institutions like the Chilean National Ballet, the Chilean National Symphony Orchestra and the Museum of Contemporary Art.

\section{How is Universidad de Chile contributing to the country's future?}

Our core mission is an orientation towards public service which addresses the country's problems and contributes to solutions that become important cornerstones of national development. Chile is undergoing a pivotal period and wants to reposition itself as an emerging country in the society of knowledge. The decline of natural resources export forces us to focus on science-based innovation. We are the main Chilean research institution and produce a third of its scientific output. Today our responsibility remains: to conduct research projects that will help Chilean society. We have changed our approach to innovation and are implementing specific policies to foster it. Between 2014 and 2016 alone we submitted 96 patent applications, resulting in 25 new technologies in areas such as engineering, biomedicine, mining and education.

\section{What are Universidad de Chile's main objectives?}

We have a strong focus on internationalization and multidisciplinary research to tackle global challenges and approach them from a local perspective. Nowadays multiple perspectives are necessary to deal with complex future scenarios. For us this has translated into the creation of interdisciplinary networks in areas such as ageing, disaster management, intelligent cities design, renewable energies and social cohesion, amongst others. We have created the Center for Mathematical Modeling, which uses mathematics to solve problems coming from other sciences, industry, and public policies.

\section{How do you interpret internationalization?}

We have been showcasing our research to create a better connection with other Latin American research bodies. Many European universities have a growing interest in connecting with South American science. Chile is a small country, but, given its level of development and its proven research capacity, we could act as a platform to strengthen the links between Latin America and more scientifically developed countries. At present, we have three-way projects that involve connections with other large Latin-American universities such as Sao Paulo, Buenos Aires and UNAM in México as well as European and North American research institutions. Universidad de Chile has also increased binational forums, with countries such as Sweden, France, and Japan, to promote new lines of innovative research in areas ranging from astronomy to social sciences.

\section{What is the Caren project about?}

Caren has been conceived as a modern science city, rather than a technological or industrial park. It will host impressive museums such as The Darwin in Chile Museum and the Natural Disasters Museum which will reflect the nature of Chile as a place prone to earthquakes, tsunamis and other natural phenomena. The multidisciplinary approach will proliferate in Caren, and the city will also host several university networks. In Caren, academics will physically come together with public research institutions as well as private companies which, in South America, are generally reluctant to invest in R\&D.

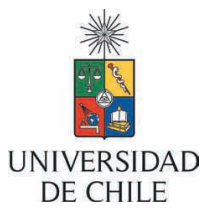




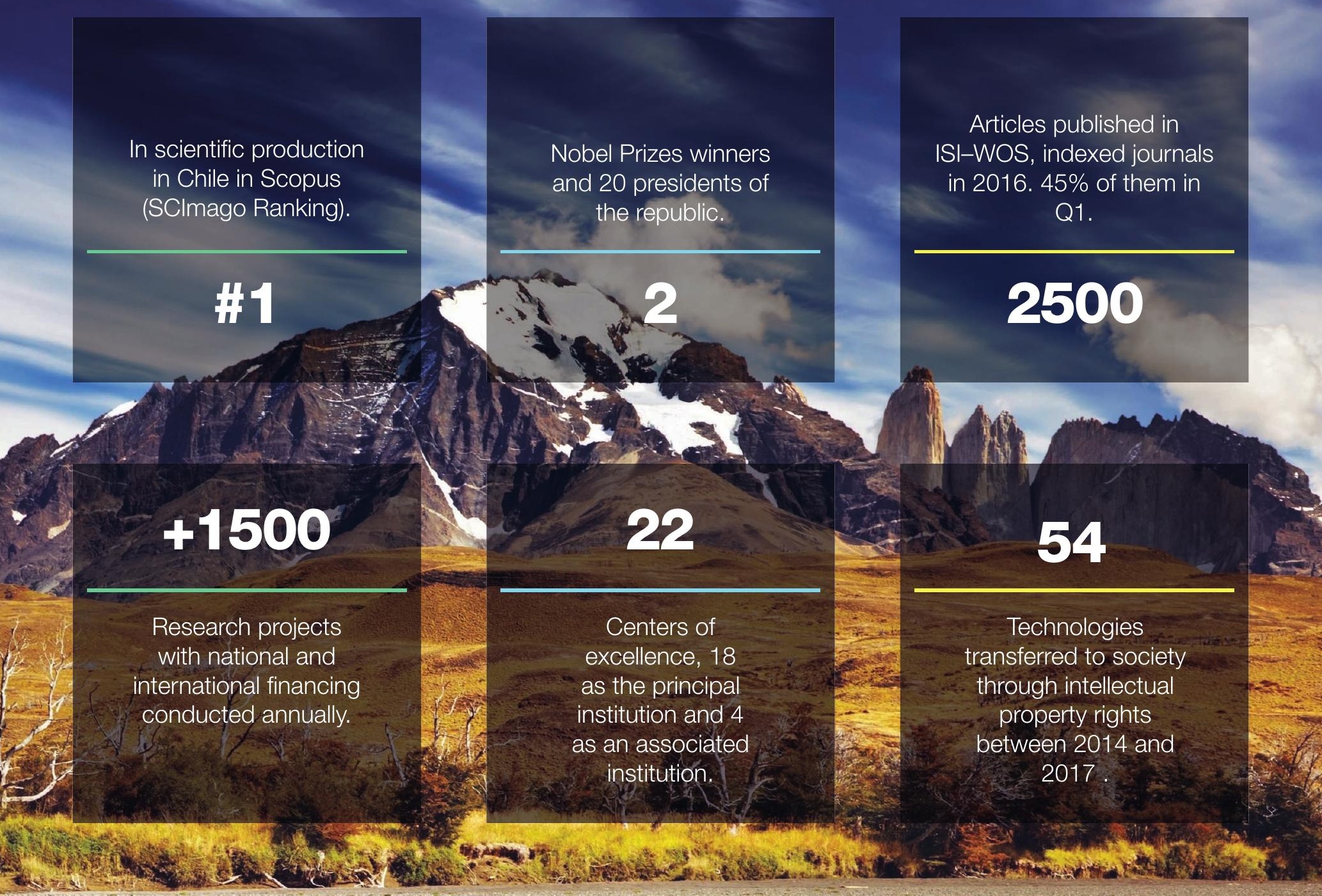




\title{
CHILE'S UNIVERSIDAD ANDRÉS BELLO IS YOUNG AND REACHING FOR THE STARS
}

\author{
A conversation with ARIEL ORELLANA, vice rector of research at Universidad Andrés Bello
}

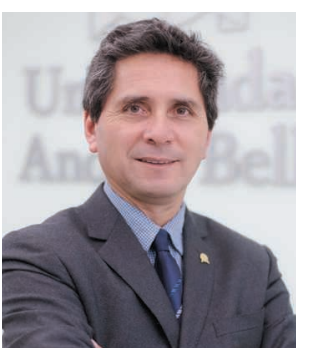

Founded in 1988, Universidad Andrés Bello's youth is belied by its ranking and reputation. Recognised in Chile by the National Commission of Accreditation, it is also accredited by the Middle States Commission on Higher Education in the US. In 2017 it was among the top four Chilean institutions in the Shanghai Ranking survey, and in the Scimago Institutions Ranking, the Santiago-based university was third nationally. Ariel Orellana, its vice rector of research, describes how the university has matured.

\section{How has Universidad Andrés Bello built up scientific strengths so quickly?}

There was a firm commitment to develop research as part of the university's mission. It brought an active interest in hiring faculty with research experience - leading to the gathering of senior faculty members and talented young academics. In the beginning the focus was on chemistry and biological sciences, and then physics, astronomy, ecology, engineering, education, social sciences and the humanities, among others, were developed. As a consequence, different $\mathrm{PhD}$ programmes have been created, supporting research growth.

\section{How has the university made itself an attractive place to do research?}

We have a strong commitment towards research, with efficient policies and academic quality assurance mechanisms that have allowed us to become highly competitive: internal funding for research grants in different disciplines, support to attend international conferences, great access to equipment as well as protected time allocation for research projects.

\section{What other incentives do you provide for researchers starting their careers?}

Chile's main funding agency is the National Fund for Scientific and Technological Research (FONDECYT). Researchers with FONDECYT grants are allowed to use the overhead (17 percent) to provide additional support to their initiatives, such as for equipment and travel.

\section{What is the research culture like at Andrés Bello?}

We have a young and vibrant community that is expanding.

There is a spirit of shared common interest, and in the last five years, three of our researchers won the award for the most distinguished young Chilean scientist in the field of biology. Most researchers are bound to research units such as centres or departments, where common research interests favour collaborative work, attracting $\mathrm{PhD}$ and masters students. In the humanities, social sciences and nursing, there is an increasing development of interdisciplinary programmes.

\section{What kinds of work are your} most vibrant groups doing?

Astronomers are active in major discoveries, such as the recent observation of a 'kilonova' generated by the fusion of neutron stars. The first Chilean dinosaur ever described, which was reported in Nature, was discovered by a geologist from Universidad Andrés Bello. Chemists are carrying out world-class applied physical and theoretical chemistry with impacts on new developments in material sciences and catalysts, while researchers in biological sciences are driving new insights in neuroscience, structural biology, microbiology and plant biology.

\section{Why is astronomy such a strength in Chile, and particularly at Andrés Bello?}

Because we have clear skies throughout the year, the European Southern Observatory (ESO) and the Atacama Large Millimeter/ submillimeter Array (ALMA) of radio telescopes, among others, were built here. Chilean astronomers are guaranteed ten percent of the observation time at these facilities. It was natural for the university to develop this field, so we have an undergraduate programme, a PhD programme in astrophysics and a very active research group in astronomy.

\section{Any other international consortiums?}

We participated in international biotechnology efforts to publish the peach genome and the strawberry genome. We are part of the Latin American Chinese European Galaxy Formation Network (LACEGAL). In addition, our researchers collaborate with top research centres worldwide.

\section{Why are such international collaborations important?} Trying to publish in high-impact journals from Chile is not easy, unless you have a network of people. Having collaborations with the US and Europe allows us to get access to infrastructure and equipment.

How are you drawing international students?

We are getting a significant number from Latin America - Argentina, Colombia, Peru.
Our graduate programmes in chemistry, biotechnology and molecular biosciences in particular are becoming known at an international level.

What is an example of why Andrés Bello is a good place to do research?

We are a very flexible institution. Being a younger university, we have an efficient management system which can make things happen more quickly than at other institutions. For instance, we have a group of young researchers who excel at working with anaerobic microorganisms, so we made certain the group has the infrastructure it needs.

Any other major infrastructure developments?

We are creating a new building for experimental research, with 5,000 square metres of lab space that will contain animal facilities and cutting-edge equipment for cell sorting, atomic force microscopy, and a physical properties measurement system (PPMS). We were the first research university in Chile to provide $X$-ray facilities for research in chemistry, material sciences and geology. We are also pursuing the highest standards of research equipment in cell biology, with state-of-the-art confocal microscopy.

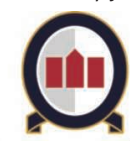

Universidad Andrés Bello. 


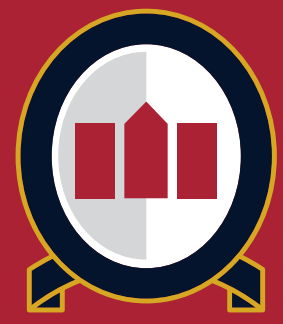

\section{Universidad Andrés Bello}

\section{PRESTIGIOUS WORLD RANKINGS RECOGNIZE OUR UNIVERSITY AMONG THE BEST IN THE COUNTRY}

AMONG THE THREE BEST

UNIVERSITIES IN THE COUNTRY ACCORDING TO SCIMAGO INSTITUTIONS RANKINGS

SCIMAGO
IIII INSTITUTIONS RANKINGS
AMONG THE FOUR BEST UNIVERSITIES IN THE COUNTRY ACCORDING TO ACADEMIC RANKING OF WORLD UNIVERSITIES SHANGHAI 2017
AMONG THE FOUR BEST UNIVERSITIES IN THE COUNTRY ACCORDING TO UNIVERSITY RANKING BY ACADEMIC PERFORMANCE

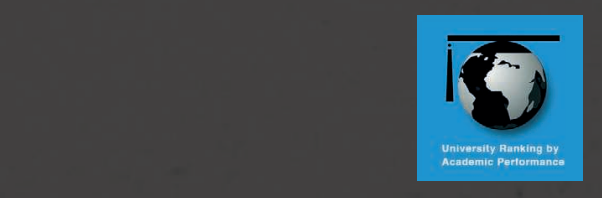

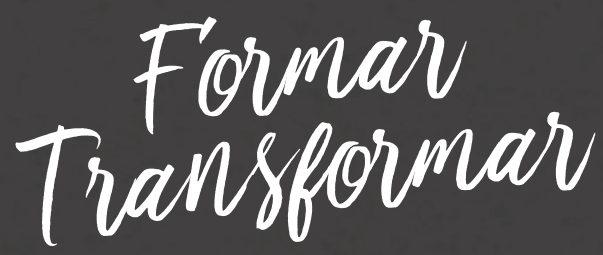




\section{CHILE: A NATURAL LAB FOR THE EXTREMES OF SCIENCE}

\section{A conversation with MYRIAM GÓMEZ, executive director of Brand Chile}

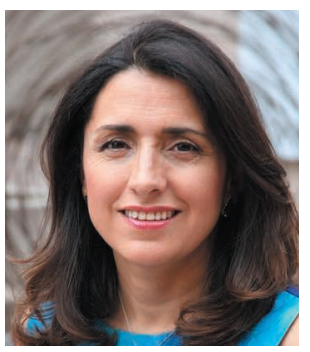

Chile is among the world's narrowest and longest countries. Its unique geography ranges from the driest desert on Earth in the north, Atacama, to the fjords and glaciers of the Patagonia and the Antarctic in the south, along a 4,000 km Pacific Ocean coastline and the world's longest continental mountain range, the Andes. This makes the country an exceptional natural lab that could hold answers to some of the most pressing scientific questions.

What makes Chile an attractive destination for worldwide researchers?

Chile's geography is an open invitation to explore the diversity of our planet in a single place. This diversity makes it a fascinating destination for worldwide researchers, a true natural laboratory that will underpin advances in astronomy, seismology, oceanography, volcanology and glaciology, amongst many others. Chile has the potential to become a key nation that contributes to finding solutions to global challenges.

\section{What are some of Chile's competitive advantages over other South American countries, Europe and the United States?}

Our country has everything necessary to generate strong long-term international scientific work, as reflected by the sustained investment that the most prestigious European astronomical institutions have placed here. They rely on Chile to install the main observatories on Earth due to our political and economic stability. We have proved a reliable partner when it comes to commitments, and our position in the Global Entrepreneurship, Innovation and Logistic Performance indexes is proof of this. China has also committed to building a telescope in the north of Chile, one of the first outside Asia.

Regarding Europe and the
US, we can offer a unique place for astronomists to decode and discover the Universe, due to the dryness of our desert, clear skies and the lack of light pollution. We also have pristine areas in Cape Horn, located in the extreme southern part of the hemisphere, which includes the remote subantarctic rainforest in the Magellanic region, making it an ideal place to study climate change.

What are the natural conditions that make Chile such an exceptional place?

The Atacama Desert is the area with the highest sun radiation on Earth. In the south, Chile has several uncommon ecoregions relevant to less common research areas. It has some of the highest numbers of endemic species in Latin America and ecoregions of global importance due to their biodiversity.

Our territory extends over several ecoregions, including the subtropical forest of Rapa Nui, Sala and Gómez islands and the temperate forest of the Juan Fernández archipelago. These ecoregions include unique plants and fauna, due to their isolation. Likewise, the recently created Nazca-Desventuradas Marine Park represents the largest reserve of its kind on the American continent. This means an area of 297,000 square kilometers is now protected.

Chile also has 139 active volcanoes, and $75 \%$ of the total glacier surface in South
America. It has 24,093 glaciers, the third largest reservoir of freshwater on the planet.

There are 15,790 lakes and 3094 islands and small islands in the country.

The country has registered some of the strongest earthquakes on record, resulting in the national development of some of the most innovative anti-seismic solutions. These technologies have sparked interest among other countries and have been exported to Peru and New Zealand, for example.

\section{How is Chile developing a scientific infrastructure that could attract international researchers?}

The country is becoming increasingly aware of its potential in scientific matters and the specific conditions that can be developed. For example, in Magallanes (Patagonia), the regional government is considering investing US\$120 million to install the Biomedicine, Antarctic International, Remote Sensing and Sub-Antarctic centers, which should be built between 2018 and 2021, respectively. This region hopes to provide key knowledge about climate change as well as build a network of more than a thousand scientists from around the world.

\section{How are Chile's pristine areas} being protected?

This year we have seen a lot of progress in this area. Chile's government recently announced the creation of the National Parks of Patagonia Network, which will protect 4.5 million hectares of biodiversity, equivalent to the size of Switzerland.

Cape Horn and the Juan Fernández archipelago will soon become ocean parks, which will increase the country's marine protected area to more than a million square kilometers. This milestone will place Chile fifth worldwide, according to data from the International Union for Conservation of Nature (IUCN).

\section{What are Brand Chile's objectives in science?} Chile has become the world astronomy hub thanks to our ideal star-gazing conditions. We also stand out for the fast development of renewable energies and advances in environmental protection, which will continue to increase in the future.

This potential is an important part of our national identity. We are showcasing this to the world through our digital strategy, media activity and visual material, spreading the message that Chile is a place that could offer cuttingedge solutions to global challenges.

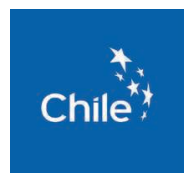




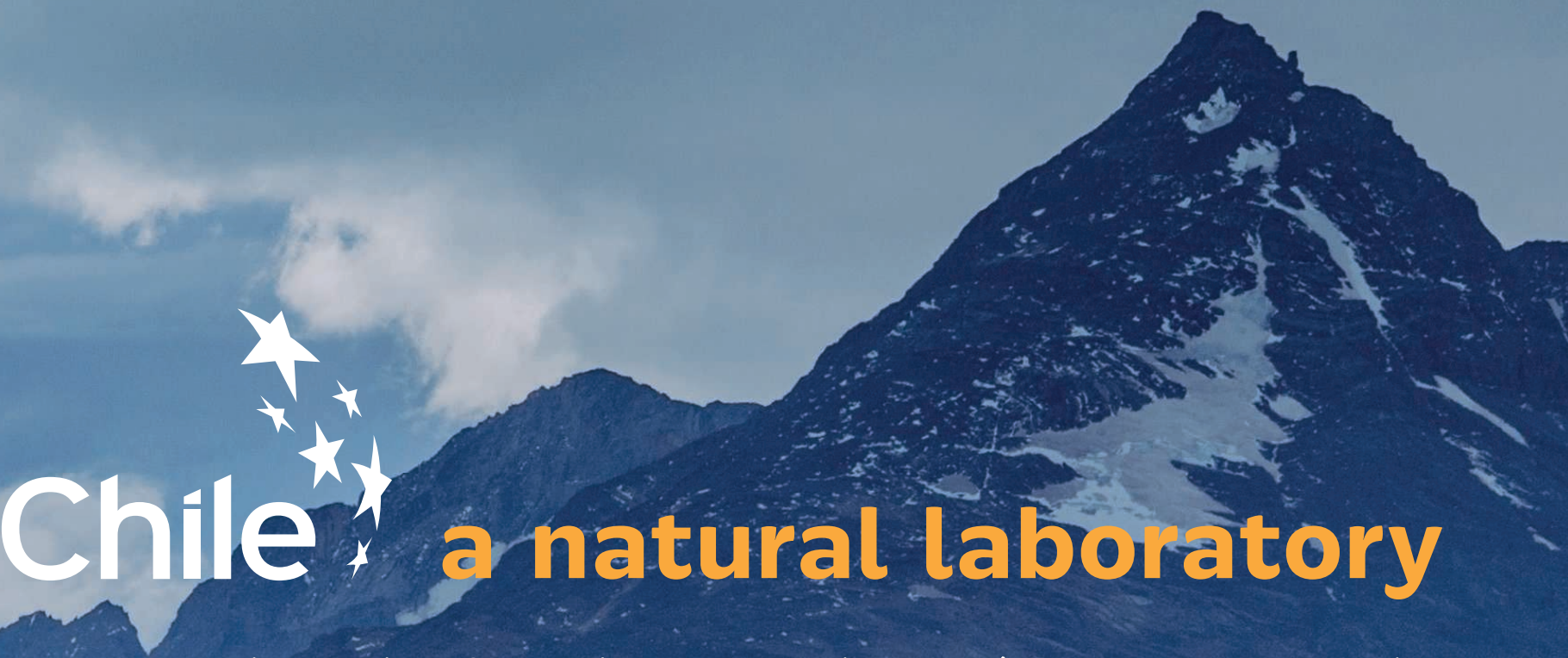

When you combine a variety of dramatic landscapes with nature's great challenges, you wind up with Chile: a gathering point for astronomers, seismologists and scientific innovators.
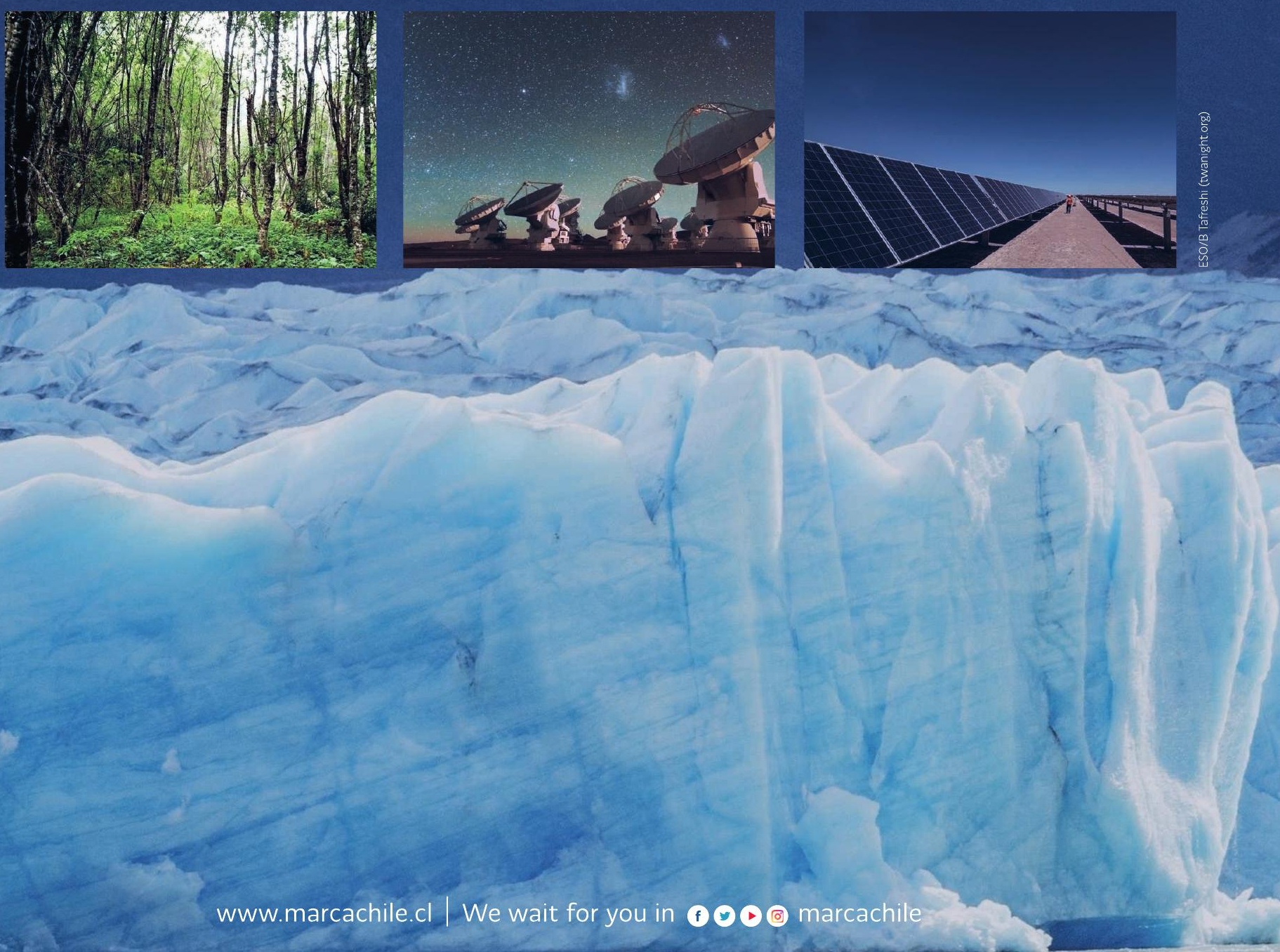

www.marcachile.cl / We wait for you in $\odot \odot \odot$ () marcachile 


\title{
PONTIFICIA UNIVERSIDAD CATÓLICA DE CHILE (PUC) TAPS INTO CHILE'S DIVERSE GEOGRAPHY
}

\author{
A conversation with IGNACIO SÁNCHEZ, president of Pontificia Universidad Católica de Chile (PUC)
}

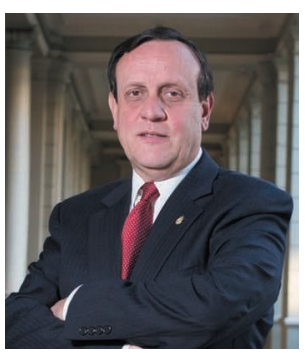

Pontificia Universidad Católica de Chile (PUC) is the nation's research powerhouse. Publishing

more than 2,400 Scopus articles per year, the Santiago-based university is both a Latin

American gateway for collaboration and a player in several international collaborations, its

president, Ignacio Sánchez, explains.

\section{Why is PUC a great university} to collaborate with?

Some of our research areas are very well positioned internationally, such as astronomy, biology, medicine, engineering, arts, and social sciences, among many others. As a leading university in Latin America, we have a reputed academic body, a strong doctoral programme, a well-developed research focus, and a unique geography that makes us an interesting partner in joint research.

\section{How does PUC's geographic location provide global research opportunities?}

PUC has developed a network of field stations throughout the country. One is in the Atacama Desert in the north of Chile, an area with some of the highest solar radiation in the world, making it an ideal place to research water capture in arid environments. Another, in Patagonia, provides amazing biodiversity. Our coastal research station includes a protected area in a pristine environment in central Chile, ideal for marine conservation. The Chiloé Island station focuses on research regarding conservation and sustainable management of the forest as well as Puerto Williams (Antarctic gateway). Finally, our campus in the lake district (Villarrica campus), where most of Chile's indigenous population (Mapuches) lives, allows us to study sustainable local development.
What about PUC's location makes it good at addressing these issues?

Chile is the longest country facing the Pacific Ocean, and it has a coastline of thousands of kilometres, while also being sheltered by the Andes Mountains. Our different climates provide unique features for different types of research. The arid north is excellent for astronomic purposes: Chile holds $70 \%$ of the world's astronomical observatories and is also a lab for extra-terrestrial technologies. Our extreme conditions allow researchers to study extremophile microorganisms, both in the north and south of Chile. Our university's research is conscious of this uniqueness, and takes advantage of these features.

\section{How does PUC offer collaborators a gateway into Latin American issues?}

We are part of centres of excellence on social conflicts and cohesion, on educational justice and on intercultural and indigenous studies. We also host a centre on sustainable urban development, and the J-PAL Center for Latin America and the Caribbean, a Poverty Action Lab originally established at MIT, which addresses the implementation of development policies in our region, among many other centres of excellence.

\section{How does PUC innovate in research?}

We are pioneers in creating new flexible curricular structures that promote early-stage research and foster innovation and entrepreneurship skills in our students. Our Center of Innovation is a recognized national hub whose aim is to promote the development of innovative technologies.

It hosts a variety of resources including a business incubator, a technology transfer office, a venture capital fund and a corporatesponsored research office.

\section{What are some examples of technologies developed by the university?}

We have been recognized as the leader in obtaining patents in our country for two consecutive years. For example, the Faculty of Engineering has developed anti-seismic technologies to improve the structural integrity of buildings during earthquakes. These innovations have resulted in a spin-off for the university, positioning PUC as a global leader in anti-seismic technologies. Our innovations cover a wide spectrum of fields, ranging from the development of new breeds of raspberries and the development of a detection kit for an accurate diagnosis of thyroid cancer to new solutions for social housing developed by our Pritzker Prize winner, Alejandro Aravena.

What have been some of PUC's recent successful global research collaborations? PUC participates in global initiatives in high-energy physics, such as
Daya Bay, CERN and Juno, and we also have strong collaboration in astronomy and astro-engineering with the telescopes and observatories based in Chile. We host and collaborate in several international joint centres based in Chile, such as the International Associated Laboratory on hantavirus and the International Joint Unit on biology and ecology of algae. We also participate in international centres of excellence for research and development that have been installed in Chile, including one in solar energy together with Fraunhofer from Germany; one in marine energy, which is a joint effort with Naval Group from France and Enel Green Power from Italy; and one in information technologies with INRIA from France.

\section{What would surprise people unfamiliar with PUC the most?} PUC has not only made the most of the capacities of our country's unique features, but has done some outstanding work toward the global enrichment of knowledge. I would also highlight the quality of our students and academic and scientific staff. For instance, our researchers in biology and biotechnology are in the process of implementing new vaccines and therapies to benefit mankind, such as the respiratory syncytial virus vaccine, currently undergoing clinical testing.

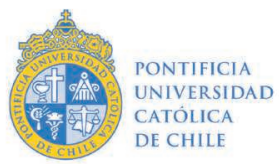




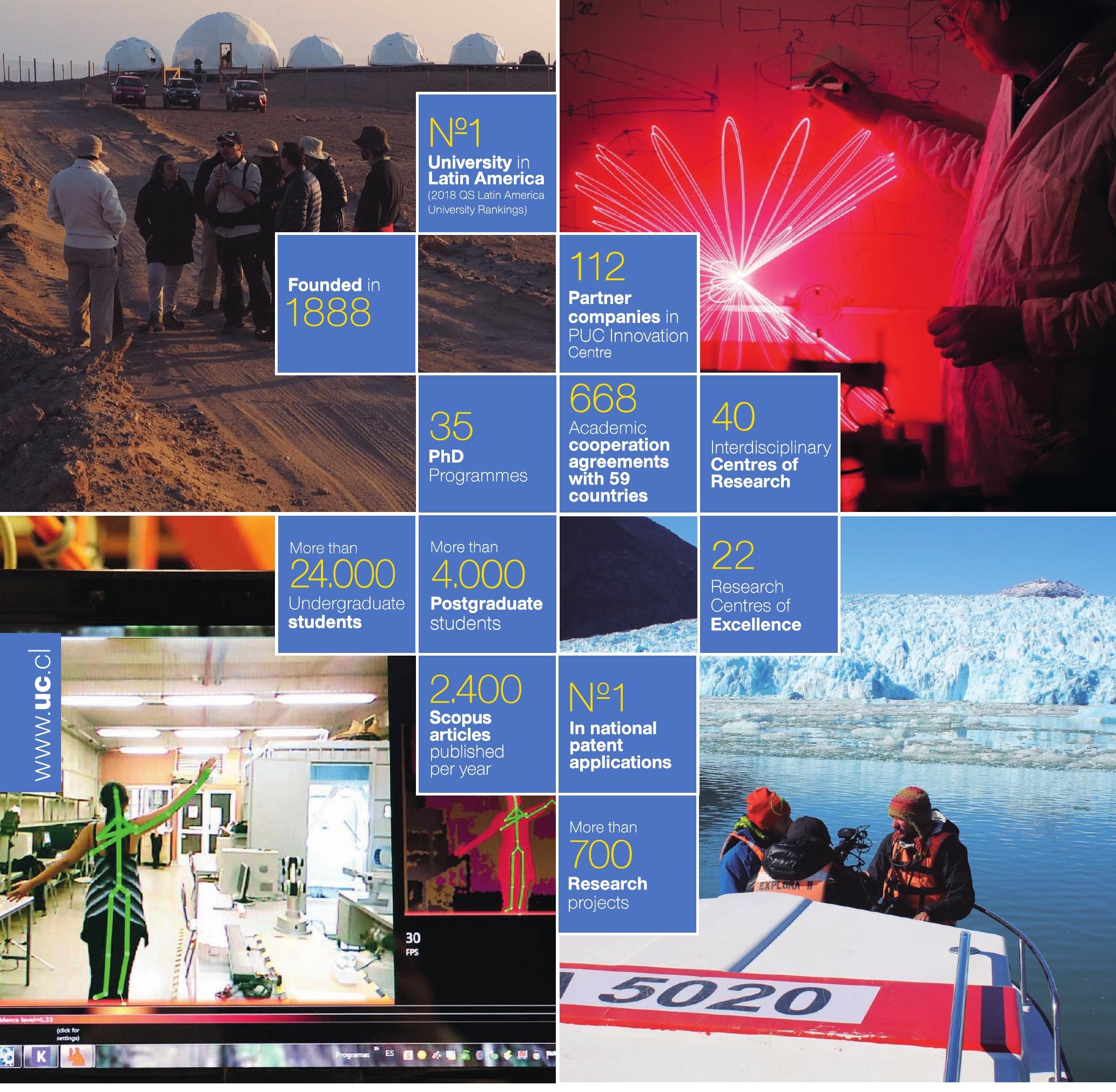

\section{Generating knowledge and cutting-edge research from Chile to the world}

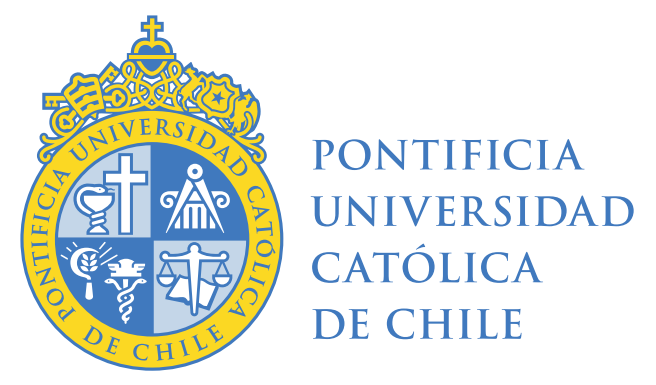




\section{Center for Advanced Studies on Educational Justice (CJE)}

CJE is a research center based at the Pontificia Universidad Católica de Chile. The CJE team of 30 researchers and their associates at other universities in Chile and abroad develop interdisciplinary and cutting-edge research to identify and understand how exclusion and inclusion are produced within school systems, with the goal of proposing more inclusive educational policies and pedagogical practices.

Director: Andrés Bernasconi.

\section{Research Lines/Leading Researchers}

1. Pedagogical Inclusion: Teaching in Diverse Classrooms Ernesto Treviño

2. Disability Inclusion: From Policies to Interventions in Special Education Ricardo Rosas

3. BioSocioCultural Inclusion: Challenging Homogeneity Claudia Matus

4. Psychosocial Inclusion: The Impact of the Mental Health of Minorities Alejandra Caqueo-Urizar

5. Developmental Inclusion: Early Childcare Arrangements for All Marigen Narea

6. Institutional Inclusion: Challenges of New Regulations under Privatization . Alejandro Carrasco

CJE is an investment of USD 5.5 million over five years (2017-2021) from Chile's National Council for Scientific and Technological Research (PIA-CIE 160007).

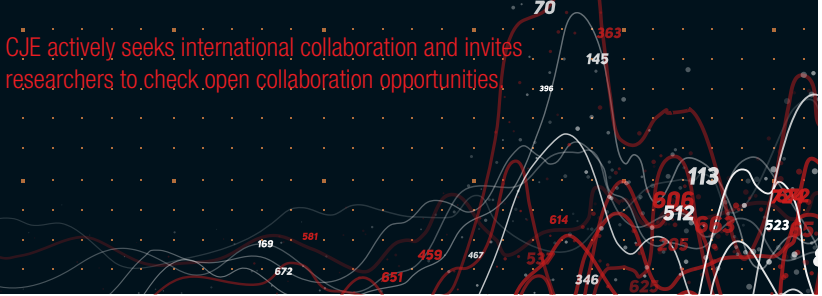




\section{Eero}

The Geroscience Center for Brain Health and Metabolism, GERO, is the first center in Latin America devoted to the Study of aging. It's funded by the National Commission for Scientific and Technological Research's FONDAP Program for Research Centers in Priority Areas.

GERO is a multidisciplinary center, with strong focus on brain diseases, integrating fundamental in different hallmarks of aging with clinical research, seeking to improve the elderly's quality of life by extending their healthspan. We pursue our mission through conducting integrative studies on the Chilean aging population aimed at unravelling the contributing factors associated with both healthy and pathological brain aging.

Chile is the country of all America with the highest aging population. In 2050 one every 4 people will be over 60 years old. Here at GERO we are actively developing intervention strategies to improve quality of life and increase the healthspan of our elderly.

\section{Research areas:}

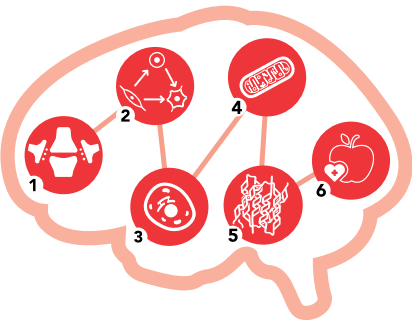

1. Neuron-Glia communication

2. IPSC and reprograming

3. Cellular senescene

4. Mitochondrial dysfunction

5. Proteostasis

6. Metabolic and nutrient sensing
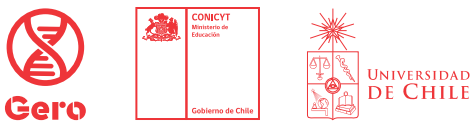